\section{Emerging Palm Diseases in Florida}

\author{
Monica L. Elliott ${ }^{1}$
}

Additional Index words. 'Candidatus Phytoplasma palmae', fusarium wilt, Fusarium oxysporum, lethal yellowing, phytoplasma, rachis blight, texas phoenix palm decline

SUMMARY. Since the mid-1990s, several new pathogens and diseases have emerged on palms (Arecaceae) growing in Florida. These include two formae speciales of Fusarium oxysporum, with $\mathrm{f}$. $\mathrm{sp}$. canariensis causing fusarium wilt of canary island date palm (Phoenix canariensis) and a new forma specialis causing Fusarium wilt of queen palm (Syagrus romanzoffiana) and mexican fan palm (Washingtonia robusta). The texas phoenix palm decline phytoplasma ('Candidatus Phytoplasma palmae' subgroup 16SrIV-D), which causes a lethal yellowing-type disease, has been detected in date palms (Phoenix spp.), queen palm, and cabbage palm (Sabal palmetto). New rachis (petiole) blight pathogens include Cocoicola californica on mexican fan palm and Serenomyces species on several palm species.

$\mathrm{F}$ or many years, the palm disease spectrum in the Florida landscape had been relatively stable, with lethal yellowing (a phytoplasma disease caused by 'Candidatus Phytoplasma palmae' subgroup 16SrIVA) and ganoderma butt rot (a fungal disease caused by Ganoderma zonatum) as the two most prominent diseases. However, since the mid1990s, several new pathogens and diseases have been observed, presenting additional challenges to the successful growth and maintenance of palms.

Fusarium oxysporum f. sp. canariensis, the causal agent of Fusarium wilt of canary island date palm, was identified in Florida in the mid-1990s (Plyler et al., 1999). While this pathogen has been observed throughout the state in landscapes and nurseries, it has not yet developed into as serious a problem as observed in California, where the pathogen has existed since the 1970s (Feather et al., 1989). When compared with the new diseases discussed below, the observed losses are relatively minor. Interestingly, this pathogen has also been isolated from senegal date palm (Phoenix reclinata) and wild date palm (Phoenix sylvestris), exhibiting typical fusarium wilt symptoms. Pathogenicity tests are in progress to determine if the isolates are crosspathogenic on these and other date palms. As observed in Florida,

Fort Lauderdale Research and Education Center, University of Florida-IFAS, 3205 College Avenue, Davie, FL 33314

${ }^{1}$ Corresponding author. E-mail: melliott@ufl.edu. fusarium wilt on canary island date palm is a relatively slow-acting disease, often taking a year or more for the palm to decline completely.

This fusairum wilt slow decline is in stark contrast to a new disease first observed on queen palm in late 2004 and more recently (Spring 2007) on mexican fan palm (Elliott and Des Jardin, 2008), two palms used extensively in the landscape. While the initial symptoms are typical of fusarium wilt-one-sided leaf necrosis with a distinct brown stripe extending along the petiole or rachis - this disease kills the palm in only a few months. The canopy often appears to have been frozen in place, as the leaves do not droop around the trunk, but rather remain rigid, albeit totally necrotic. The disease has been observed from north of Orlando to both coasts of Florida and south to Miami-Dade and Collier counties, indicating it has likely been present, but undiagnosed, for many years. While most often observed in the landscape, it has been detected in a container nursery and two field nurseries. Molecular characterization of the pathogen indicates it is a new forma specialis of $F$. oxysporum (K. O'Donnell, personal communication).

Cross-pathogenicity studies confirm that isolates from queen palm are pathogenic on mexican fan palm and vice versa (Elliott and Des Jardin, 2008). This rather diverse host range is disconcerting, and studies are in progress to determine if other commonly grown palm species are susceptible to this pathogen. Future studies will examine susceptibility of desert or california fan palm (Washingtonia filifera) and species of the genus Syagrus, palms not widely used in Florida, but if not susceptible may provide a genetic source of tolerance to the pathogen. Based on how widespread this disease is throughout the state and observations on large, managed landscapes, it does not seem likely that the disease is spread primarily by infested pruning tools, which is considered the primary means of transmission of fusarium wilt among canary island date palms. However, tool disinfestation is still recommended when pruning palms.

The second major new disease in Florida is texas phoenix palm decline, which is caused by 'Candidatus Phytoplasma palmae' subgroup 16SrIV$\mathrm{D}$. This disease is not a new disease to the continental United States, but until 2006, it had been geographically limited to coastal southern Texas and observed almost exclusively on canary island date palm (Harrison et al., 2002). While molecular documentation is lacking, it is presumed that the phytoplasma disease documented in Corpus Christi, TX, in 2001 is the same disease observed in the lower Rio Grande Valley of Texas in the 1970s (McCoy et al., 1980).

In Fall 2006, phytoplasma disease symptoms were reported on canary island date palm, date palm (Phoenix dactylifera), and wild date palm in southern Hillsborough County, FL (south of Tampa). Molecular analysis of trunk tissue from symptomatic palms detected the texas phoenix palm decline phytoplasma (Harrison et al., 2008). How the phytoplasma reached Florida is not known, but movement of the infected vector (as yet unknown) is likely, as movement of palms from the Corpus Christi area to Florida is not routine. Since the initial identification, the phytoplasma has been detected in symptomatic palms in DeSoto, Hardee, Hillsborough, Manatee, Pinellas, Polk, and Sarasota counties (Florida Division of Plant Industry, 2008), and the palm host range has expanded to include senegal date palm, queen palm, and cabbage palm. The latter is of grave concern, as this indigenous palm is prominent in natural areas throughout Florida and into the adjoining states. This is the first time a palm native to Florida has been documented with a phytoplasma disease. Updated distribution maps of 
the disease will be posted by the Florida Division of Plant Industry.

During the initial survey for texas phoenix palm decline in Florida, three results were quite surprising (Harrison et al., 2008). First, lethal yellowing was detected in Sarasota and Manatee counties, the farthest points north that this disease has been detected. Second, a third previously unknown phytoplasma was detected in date palm and mexican fan palm (subgroup 16SrIV-F). Third, mixed infections of phytoplasmas were detected in a single palm; lethal yellowing and the third phytoplasma were detected in date palm in southern Sarasota County. Until this third phytoplasma is detected routinely, its role in palm diseases remains unknown.

How far texas phoenix palm decline will spread in Florida and adjoining states will most likely depend on the vector or vectors of the phytoplasma, which was never ascertained in Texas. Research regarding the vector is in progress in Florida. Movement of the disease within Texas should be closely monitored also. As in Florida, use of palms in Texan landscapes is increasing and certainly includes the use of date palms and cabbage palm, with the latter usually imported from Florida.

Other new pathogens for Florida palms include those associated with rachis (petiole) blights, which are not new diseases but which are unusual in that many fungal species appear to cause the same symptoms. Cocoicola californica was confirmed on mexican fan palm (Elliott and Des Jardin, 2006a). A Serenomyces species, most similar in appearance to $S$. phoenicis, was documented on canary island date palm, blue latan palm (Latania loddigesii), and the hybrid Copernicia $\times$ burretiana (Elliott and Des Jardin, 2006b). Since this report, a Serenomyces species has been observed on florida thatch palm (Thrinax radiata) and cabbage palm, both native to Florida. In most situations, rachis (petiole) blight does not appear to have a long-lasting detrimental effect on the palms beyond the initial premature loss of older leaves. In all probability, these pathogens are not "new" as much as simply "present but undetected" because the disease was never severe enough to warrant a laboratory diagnosis. The primary reason these palm samples are reaching the laboratory now is because the symptoms of rachis (petiole) blights are exactly the same as fusarium wilt. Thus, even on palms not known to be susceptible to $F$. oxysporum, observation of fusarium wilt-like symptoms prompts a closer inspection for the pathogen.

The expanding list of palm diseases has put many of our landscapes at risk, especially in the northern half of the state where the palm palette is not as extensive as in the southern half. Even in the southern half of Florida, new real estate developments often use only a few species of palms in the landscape. Thus, when a lethal disease emerges, individual properties and the entire community can be affected.

\section{Literature cited}

Elliott, M.L. and E.A. Des Jardin. 2006a. First report of Cocoicola californica on Washingtonia robusta in Florida. Plant Health Prog., doi: 10.1094/PHP-20060227-01-BR.
Elliott, M.L. and E.A. Des Jardin. 2006b. First report of a Serenomyces sp. from Copernicia $\times$ burretiana, Latania loddigesii, and Phoenix canariensis in Florida and the United States. Plant Health Prog., doi: 10.1094/PHP-2006-1213-02-BR.

Elliott, M.L. and E.A. Des Jardin. 2008. A new lethal disease of Syagrus romanzoffiana and Washintonia robusta in Florida is caused by Fusarium oxysporum. 44th Annu. Mtg., Caribbean Food Crops Soc., Miami, 13-17 July 2008 (Abstr.). 4 Jan. 2009. <http://cfcs.eea.uprm.edu// 44th_Meeting/PosterPresentations.htm>.

Feather, T.V., H.D. Ohr, D.E. Munnecke, and J.B. Carpenter. 1989. The occurrence of Fusarium oxysporum on Phoenix canariensis: A potential danger to date production in California. Plant Dis. 73:78-80.

Florida Division of Plant Industry. 2008. Texas phoenix palm decline sites. 4 Jan. 2009. <http://www.doacs.state.fl.us/ pi/caps/TPPD_maps/TPPD.pdf>.

Harrison, N.A., E.E. Helmick, and M.L. Elliott. 2008. Lethal yellowing-type diseases of palms associated with phytoplasmas newly identified in Florida, USA. Ann. Appl. Biol. 153:85-94.

Harrison, N.A., M. Womack, and M.L. Carpio. 2002. Detection and characterization of a lethal yellowing (16SrIV) group phytoplasma in canary island date palms affected by lethal decline in Texas. Plant Dis. 86:676-681.

McCoy, R.E., M.E. Miller, D.L. Thomas, and J. Amador. 1980. Lethal decline of phoenix palms in Texas associated with mycoplasma-like organisms. Plant Dis. 64:1038-1040.

Plyler, T.R., G.W. Simone, D. Fernandez, and H.C. Kistler. 1999. Rapid detection of the Fusarium oxysporum lineage containing the canary island date palm wilt pathogen. Phytopathology 89:407-413. 